\title{
PENGEMBANGAN MEDIA PEMBELAJARAN INTERAKTIF KONFIGURASI ELEKTRON ELEKTRONIK OTOMATIS MATA PELAJARAN IPA DI MASA PANDEMI COVID-19
}

\author{
Yayuk Dian Mandasari, Marianus Subandowo, Wawan Gunawan \\ Jurusan Teknologi Pendidikan, Program Pascasarjana, Universitas PGRI Adi Buana Surabaya \\ Jl. Dukuh Menanggal XII No. 4 Surabaya, Indonesia, Telp. (031) 5041097 \\ Email: b.dian.speniwa@gmail.com
}

\section{Article History}

Received: 03 Maret 2021, Accepted: 06 Juli 2021, Published: 10 Agustus 2021

\begin{abstract}
Abstrak
Tujuan dari pengembangan ini yaitu menciptakan media pembelajaran interaktif Konfigurasi Elektron Elektronik Otomatis yang berbasis Articulate Storyline yang layak serta efektif digunakan untuk mencapai hasil belajar peserta didik secara maksimal pada mata pelajaran IPA dengan materi konfigurasi elektron kelas IX SMP Negeri 1 Wonoayu Sidoarjo di masa pandemi COVID- 19. Produk berbentuk aplikasi Html5 pada pembelajaran DARING dan flashdisk/CD untuk pembelajaran LURING. Penelitian ini memanfaatkan model pengembangan ADDIE yang terdiri dari lima tahapan yang saling berkaitan, yaitu Analysis, Design, Development, Implementation, dan Evaluation. Hasil Pengembangan media pembelajaran interaktif Konfigurasi Elektron Elektronik Otomatis berdasarkan penilaian ahli isi rata-rata sebesar 98,95\%, ahli media 89,73\%, dan ahli desain 92,26\%. Penilaian tersebut tergolong dalam kriteria yang sangat baik dan kategori yang sangat layak. Hasil penilaian para ahli relevan dengan dampak pembelajaran terhadap hasil belajar peserta didik yang menunjukkan ketuntasan klasikal sebesar $88,13 \%$.
\end{abstract}

Keyword: Media Pembelajaran Interaktif; Articulate Storyline; Konfigurasi Elektron

\begin{abstract}
The purpose of this development is to create an interactive learning media for Automatic Electronic Electronic Configuration based on Articulate Storyline that is feasible and effective to use to achieve maximum student learning outcomes in science subjects with class IX electron configuration material at SMP Negeri 1 Wonoayu Sidoarjo during the COVID-19 pandemic. 19. The product is in the form of an Html5 application for ONLINE learning and flash/CD for OFFLINE learning. This study utilizes the ADDIE development model which consists of five interrelated stages, namely Analysis, Design, Development, Implementation, and Evaluation. The results of the development of interactive learning media for Automatic Electronic Electronic Configuration based on the assessment of content experts on average 98.95\%, media experts $89.73 \%$, and design experts $92.26 \%$. The assessment belongs to the very good criteria and the very feasible category. The results of the expert's assessment are relevant to the impact of learning on student learning outcomes which show classical completeness of $88.13 \%$.
\end{abstract}

Keyword: Interactive Learning Media; Articulate Storyline; Electron Configuration 


\section{PENDAHULUAN}

Wabah pandemi COVID-19 melanda dunia termasuk Negara kita tercinta Indonesia. Media pembelajaran interaktif adalah wahana untuk menyampaikan informasi pembelajaran dan dapat menjawab tantangan pembelajaran di masa pandemi COVID-19. Pelaksanaan Kebijakan Pendidikan dalam Masa Darurat Penyebaran Corona Virus Disease (COVID-19) tertuang dalam Surat Edaran Nomor 4 tahun 2020, oleh karena itu sejak bulan Maret 2020 pembelajaran dilaksanakan secara jarak jauh Dalam Jaringan (DARING) maupun secara Luar Jaringan (LURING). Pembelajaran Jarak Jauh (PJJ) ketika masa pandemi COVID-19 merupakan pembelajaran dengan menggunakan suatu media yang memungkinkan terjadi interaksi proses belajar mengajar tanpa tatap muka secara langsung (Prawiyogi et al., 2020). Selama Pembelajaran dengan Jarak Jauh, pendidik diharapkan dapat pengembangkan profesionalisme ketika proses pembelajaran, yaitu melakukan pembaruan dan inovasi (Amirudin, 2019). Hal tersebut berdasarkan Peraturan Pemerintah nomor 19 tahun 2017 yang menyatakan bahwa pendidik memiliki kompetensi untuk menggunakan informasi maupun teknologi komunikasi yang secara fungsional relevan dengan kurikulum 2013 agar pendidik lebih inovatif.

Pendidik lebih baik menggunakan media selama proses pembelajaran demi tercapainya tujuan pembelajaran. Secara garis besar keberhasilan Pembelajaran secara Jarak Jauh di Indonesia ketika Pandemi COVID-19 ditentukan oleh kesiapan teknologi sejalan dengan kurikulum humanis nasional, dukungan dan kolaborasi dari semua pemangku kepentingan, termasuk pemerintah, sekolah, pendidik, orang tua dari peserta didik dan komunitas (Rasmitadila et al., 2020). Keberadaan media pembelajaran interaktif memiliki arti dan makna yang cukup penting dalam proses belajar mengajar, karena pada kegiatan tersebut ketidakjelasan bahan yang disampaikan dapat dibantu dengan menghadirkan media sebagai perantara. Hal itu sesuai dengan karakter pendidikan yaitu merangsang pemikiran kritis seseorang dan dapat memilih alasan yang sesuai dari setiap aktivitas kegiatan pembelajaran yang dilakukan (Satianingsih et al., 2020).

Mata pelajaran Ilmu Pengetahuan Alam (IPA) atau sains memiliki ciri khusus yang tidak sama dengan mata pelajaran lain. Dalam mata pelajaran IPA terdapat materi yang tidak memungkinkan ditampilkan secara langsung di hadapan peserta didik, akibat adanya keterbatasan ruang dan waktu. Misalnya menghadirkan benda atau makhluk yang besar di dalam kelas ataupun sebaliknya, kita tidak bisa menghadirkan benda-benda yang mikroskopis di hadapan peserta didik ketika proses pembelajaran berlangsung (Aulia et al., 2020).

Sesuai dengan analisis yang dilakukan terhadap penilaian di tengah semester ganjil Tahun Ajaran 2020/2021, diperoleh hasil yang tidak memuaskan. Di kelas IX-A, IX-B, IX-C, IX-I, dan IX-J selama masa BDR (Belajar Dari Rumah) data nilai yang diperoleh rata-rata sebesar 67,67 lebih kecil dari Kriteria Ketuntasan Minimal yang ditetapkan di SMP Negeri 1 Wonoayu Sidoarjo yaitu 77. Hal tersebut mengisyaratkan bahwa ketika proses pembelajaran IPA berlangsung, kebanyakan peserta didik tidak semangat dan kurang termotivasi dalam belajar, sehingga hasil belajarnya juga masih banyak yang di bawah Kriteria Ketuntasan Minimal. Terlebih lagi nanti ketika materi konfigurasi elektron yang dianggap sebagai momok dan materi yang paling sulit pada mata pelajaran IPA, karena atom dan partikel atom yaitu proton, neutron dan elektron tidak dapat diamati oleh indera penglihatan sehingga materi tersebut bersifat abstrak.

Banyak platform maupun media online yang dapat diakses melalui jaringan internet oleh pendidik maupun peserta didik (Abidin et al., 2020). Multimedia yang diterapkan di kelas dapat menarik perhatian peserta didik (Yuda et al., 2020). Pada masa lampau media yang digunakan dalam pembelajaran hanya menggunakan alat sederhana, namun kini telah berkembang (Herdiyanto et al., 2020). Pembelajaran dengan jarak jauh di masa pandemi COVID-19 dapat diperbaharui suasana pembelajarannya dengan inovasi sehingga peserta didik lebih termotivasi. Motivasi untuk meraih capaian belajar yang maksimal merupakan suatu dorongan atau motif yang terdapat pada setiap 
peserta didik untuk mengarahkan perilaku dalam mencapai keberhasilan pembelajaran dan pendidikan (Andriani et al., 2020).

Dari sekian banyak program authoring tools, media pembelajaran Articulate Storyline merupakan salah satu alternatif media interaktif. Para designer pembelajaran dari tingkat pemula hingga tingkat expert dapat dibantu oleh Articulate Storyline yang merupakan software Mix Programming Tools. Program Articulate Storyline memiliki kelebihan yaitu smart brainware yang sederhana dengan prosedur tutorial interaktif melalui template yang bisa ditampilkan secara offline maupun online (Sudibjo, 2019). Fitur Articulate Storyline yang lengkap layaknya flash dan interface semudah Power Point menjadikan Articulate Storyline dapat dimanfaatkan sebagai multimedia interaktif (Darnawati et al., 2019).

Penelitian yang dilakukan oleh Setyaningsih et al. (2020), menunjukkan hasil nilai rata-rata pre test sebesar 63,33 dan post test sebesar 84,89 lebih tinggi dari nilai KKM 75. Sebaliknya nilai rata-rata pre test kelas kontrol hanya sebesar 59,33 dan post test 74,88 . Penelitian tersebut membuktikan bahwa hasil belajar peserta didik kelas IV SD Negeri Gubeng I/204 Surabaya pada materi kerajaan Hindu Budha di Indonesia dipengaruhi oleh penggunaan media pembelajaran interaktif berbasis Articulate Storyline. Sedangkan penelitian lain yaitu Hamdani dan Priatna (2020), berdasarkan hasil survei menunjukkan bahwa peserta didik merasa nyaman menggunakan pembelajaran DARING sebesar $65,78 \%$, sedangkan sisanya yang merasa kesulitan sekitar 34,22\%, hal ini membuktikan bahwa peserta didik sekarang sudah banyak yang paham akan teknologi.

Berdasarkan permasalahan sebagaimana yang dikemukakan di atas, maka tujuan yang akan dicapai dalam penelitian ini yaitu memproduksi media pembelajaran interaktif Konfigurasi Elektron Elektronik Otomatis. Articulate Storyline dijadikan program authoring tools dalam memproduksi media pembelajaran tersebut. Produk yang dihasilkan layak dan efektif diterapkan pada mata pelajaran IPA dengan materi konfigurasi elektron kelas IX SMP Negeri 1 Wonoayu Sidoarjo di masa pandemi COVID-19 untuk meningkatkan hasil belajar peserta didik.

\section{METODE}

ADDIE merupakan model pengembangan yang akan digunakan dalam penelitian ini, yaitu model pengembangan yang terdiri dari lima tahapan yang saling berkaitan, yakni Analysis (analisis), Design (perencanaan), Development (pengembangan), Implementation (penerapan), Evaluation (evaluasi) (Molenda, 2015). Pendapat Pujianto, H. et al. (2020) dan Noviyanti dan Gamaputra (2020), mengartikan bahwa ADDIE merupakan sebuah konsep pengembangan yang meliputi Analisa, Perancangan, Pengembangan, Implementasi, dan Evaluasi. Pengembangan media ini menerapkan model ADDIE karena rasional, sistematis, tidak sulit dipelajari dan lengkap. Model ADDIE tersusun dengan sistematis sehingga dalam pelaksanaannya urut, setiap tahap yang dilalui selalu berpatokan pada tahap sebelumnya yang telah melalui proses revisi maupun perbaikan sehingga tahap berikutnya diperoleh produk media pembelajaran yang efektif (Supratman dan Purwaningtias, 2018).

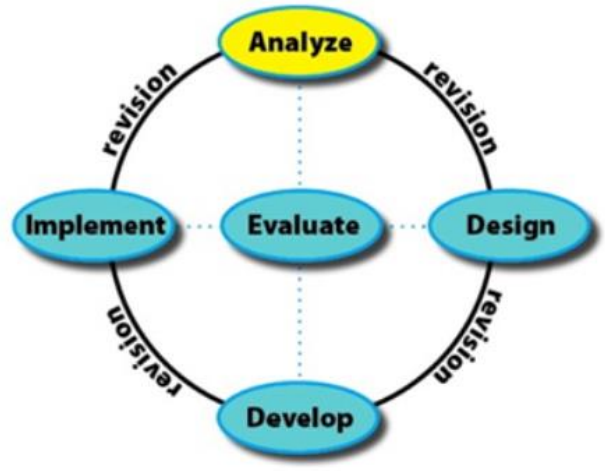

Gambar 1. Prosedur Pengembangan Model ADDIE 
Uji coba produk melalui 2 tahap yakni: (1) uji validasi dan (2) uji produk. Uji validasi melibatkan 3 ahli yaitu ahli isi, ahli media, dan ahli desain. Uji coba produk meliputi 3 tahap yakni 4 peserta didik pada uji perseorangan, 8 peserta didik pada uji kelompok kecil, dan 32 peserta didik pada uji lapangan (Iswara et al., 2020). Pengujian validitas instrumen yang digunakan dalam penelitian ini adalah validitas konstrak/construct validity (Fatirul dan Rufi'i, 2020). Angket untuk para ahli dan peserta didik memiliki skor dengan value range 1 dan skor maksimum 5 (Wijayanti, 2020).

Untuk menentukan tingkat konsensus para ahli dan persepsi peserta didik digunakan perhitungan skor dengan dua rumus yang bersumber dari Luhulima (2018), sebagai berikut:

1) $P=\left(\frac{X}{X_{1}} \times 100 \%\right)$ Keterangan untuk rumus tersebut adalah: $P$ menunjukkan persentase $(\%)$ jawaban, $\mathrm{X}$ adalah jumlah skor jawaban seluruh responden dalam satu item, dan $\mathrm{X}_{1}$ adalah jumlah skor maksimum dalam satu item.

2) $P=\left(\frac{\Sigma X}{\Sigma X_{1}} \times 100 \%\right)$ Keterangan untuk rumus tersebut adalah: $\mathrm{P}$ menunjukkan persentase $(\%)$ jawaban, $\sum X$ adalah jumlah keseluruhan skor jawaban responden, dan $\sum X_{1}$ adalah jumlah keseluruhan skor maksimum.

\section{HASIL}

Analysis adalah tahap pertama bagi peneliti untuk mencari suatu potensi masalah (Saputri dan Oktarin, 2019). Sesuai dengan analisis kinerja, peneliti menemukan permasalahan yaitu akibat pandemi COVID-19 pembelajaran dilakukan secara jarak jauh. Pembelajaran dengan Jarak Jauh dapat berupa Pembelajaran Jarak Jauh di Dalam Jaringan (PJJ DARING) dan Pembelajaran Jarak Jauh di Luar Jaringan (PJJ LURING). Sedangkan analisis kebutuhan diperoleh hasil bahwa peserta didik dalam mencapai ketuntasan hasil belajar pada Kompetensi Dasar, dibutuhkan media pembelajaran interaktif yang dapat digunakan secara DARING maupun LURING.

Tahapan design meliputi beberapa perencanaan produksi media pembelajaran (Cahyadi, 2019). Indikator yang akan dicapai yaitu: menjelaskan atom dan partikel-partikel penyusun atom; mengidentifikasi nomor atom dan nomor massa; dan mendeskripsikan terbentuknya konfigurasi elektron. Articulate Storyline merupakan program authoring tools yang dijadikan dasar pengembangan media pembelajaran interaktif Konfigurasi Elektron Elektronik Otomatis. Produk berupa software Html5 untuk pembelajaran secara DARING dan flashdisk/CD untuk pembelajaran LURING.

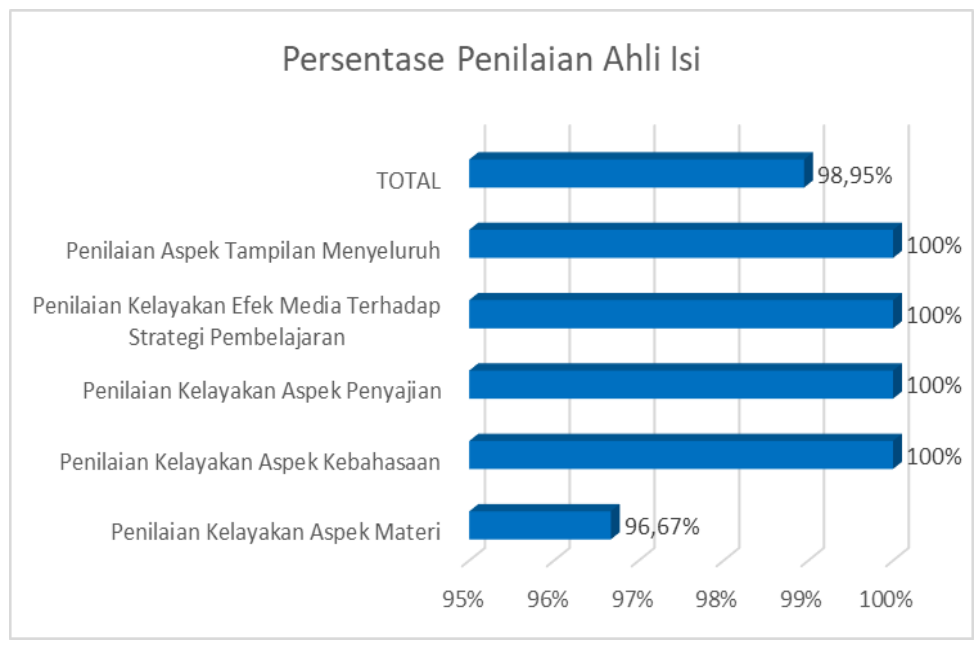

Grafik 1. Persentase Penilaian Validasi Ahli Isi

Tahap development meliputi pra produksi, produksi, dan pasca produksi (Fatirul, 2020). Pada tahap pra produksi dilakukan tinjauan pustaka dan observasi capaian hasil belajar peserta didik selama pembelajaran secara jarak jauh ketika masa pandemi COVID-19. Tahap memproduksi media pembelajaran interaktif Konfigurasi Elektron Elektronik Otomatis sesuai dengan Kompetensi Dasar 
dan Indikator pembelajaran yang ditetapkan pada tahap perencanaan. Pada tahap pasca produksi dilakukan validasi produk oleh ahli isi, ahli media, dan ahli desain (Novianto et al., 2018).

Hasil analisis validitas ahli isi pada grafik 1, memberikan makna bahwa produk yang dikembangkan telah dipandang sangat layak untuk diimplementasikan. Hasil tanggapan ahli isi di atas $85 \%$, sehingga menunjukkan bahwa isi valid untuk disajikan dalam pembelajaran.

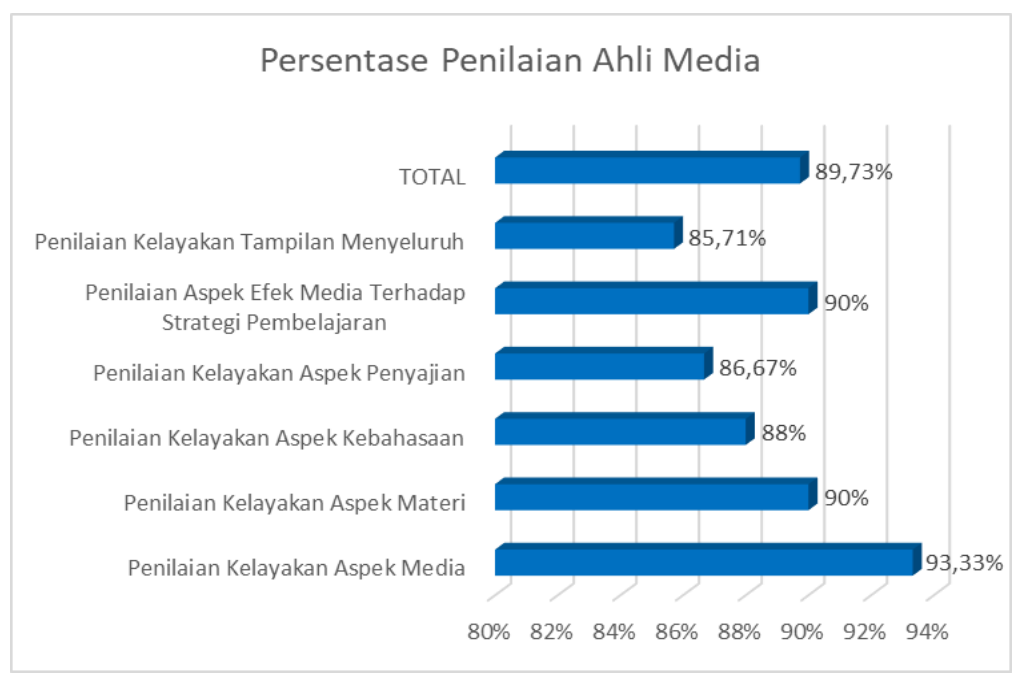

Grafik 2. Persentase Penilaian Validasi Ahli Media

Hasil analisis validitas ahli media pada grafik 2 memberikan makna bahwa produk yang dikembangkan telah dipandang sangat layak untuk diimplementasikan. Rerata tanggapan ahli media lebih dari $85 \%$, mengindikasikan bahwa media valid untuk pembelajaran.

Hasil analisis validitas ahli desain pada grafik 3 memberikan makna bahwa produk yang dikembangkan telah dipandang sangat layak untuk diimplementasikan. Tanggapan positif dari ahli desain lebih dari $85 \%$ memberikan petunjuk bahwa desain layak untuk menjadi media pembelajaran.

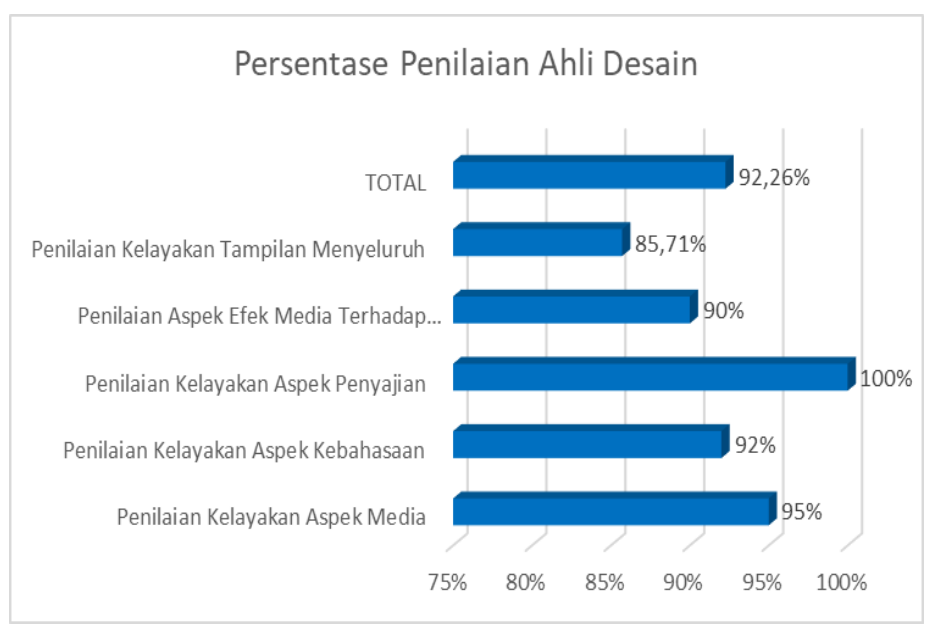

Grafik 3. Persentase Penilaian Validasi Ahli Desain

Berdasarkan hasil analisis terhadap data-data yang diperoleh dari uji coba para ahli, produk yang dihasilkan telah dinyatakan sangat layak diimplementasikan dengan beberapa saran perbaikan yang menyertainya, yaitu pada penilaian kelayakan aspek kebahasaan dengan indikator penggunaan simbol mendukung kemudahan memahami alur materi, ahli isi memberikan saran agar pada scenes materi, lambang unsur dibuat lebih besar dan berwarna. 
Uji coba penerapan media pembelajaran interaktif Konfigurasi Elektron Elektronik Otomatis pada peserta didik kelas IX dilakukan setelah produk divalidasi oleh ahli isi, ahli media, dan ahli desain. Agar menghasilkan produk yang berkualitas maka perlu dilakukan uji coba penerapan terhadap produk media pembelajaran (Yahya et al., 2020). Media dikatakan efektif apabila diperoleh tingkat persentase keberhasilan nilai peserta didik tinggi, sedangkan sebaliknya dikatakan tidak efektif jika tingkat persentase keberhasilan nilai peserta didik rendah (Arifin et al., 2018). Media disebut praktis atau tanpa revisi apabila diperoleh tingkat persentase kepraktisan tinggi, sedangkan sebaliknya dikatakan tidak praktis jika tingkat kepraktisannya rendah (Mahmudah dan Pustikaningsih, 2019).

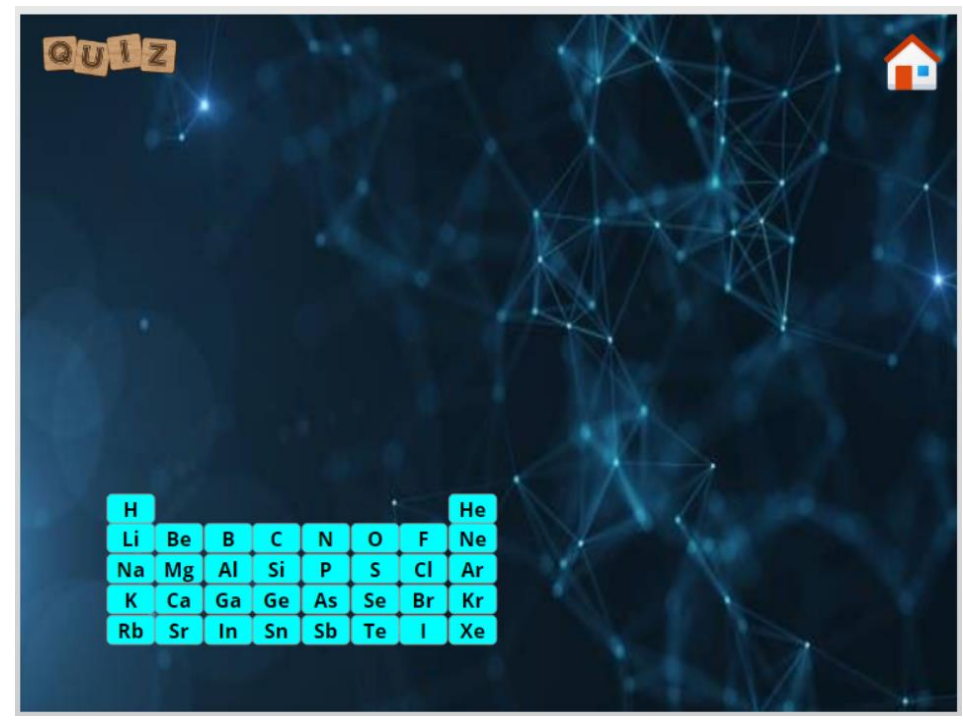

Gambar 2. Tampilan Lambang Unsur

Total penilaian terhadap keseluruhan komponen/aspek persepsi peserta didik pada uji coba perseorangan rata-rata sebesar 95,29\% dan pada uji coba kelompok kecil rata-rata sebesar 95,73\%, serta pada uji coba lapangan rata-rata sebesar 99,23\%. Penilaian tersebut tergolong dalam kriteria sangat setuju dan tingkat persepsi sangat baik. Nilai rata-rata yang diperoleh dari hasil post test pada uji coba lapangan menunjukkan ketuntasan belajar klasikal sebesar $88,13 \%$.

\section{PEMBAHASAN}

Menurut Wahyuningtyas (2019), kata media merupakan bahasa latin medist yang secara harfiah berarti "tengah" atau "pengantar". Media pembelajaran ialah alat untuk menyampaikan informasi yang dapat digunakan oleh pendidik kepada peserta didik terkait dengan pembelajaran sehingga mudah dipahami. Media pembelajaran menjadi bagian tak terpisahkan dari kegiatan pembelajaran di sekolah. Memanfaatkan media pembelajaran untuk menciptakan pengalaman yang dapat membantu proses belajar peserta didik merupakan upaya kreatif dan sistematis. Untuk menumbuhkan motivasi belajar agar peserta didik tidak mudah bosan dalam mengikuti proses pembelajaran dibutuhkan media yang berperan sebagai alat perangsang belajar. Akan tetapi, perlu dicatat bahwa pemiliham media harus sesuai dengan tujuan pembelajaran dan kompetensi yang ingin dicapai (Hakim, 2018).

Berdasarkan Nugroho, M., F. et al. (2020), manfaat media pembelajaran antara lain: (a) meningkatkan proses hasil belajar karena dapat memperjelas penyajian suatu informasi, (b) menimbulkan motivasi belajar, interaksi peserta didik, dan kemandirian belajar peserta didik karena dapat meningkatkan dan mengarahkan perhatian anak, (c) dapat mengatasi keterbatasan daya indera, ruang dan waktu, (d) memungkinkan terjadinya interaksi dan memberikan kesamaan pengalaman kepada peserta didik tentang peristiwa-peristiwa di lingkungan mereka.

Definisi multimedia berdasarkan Munir (2020), merupakan sistem komunikasi dan perpaduan media berbasis personal komputer yang mempunyai kiprah untuk membangun, menyimpan, menghantarkan dan mendapat keterangan pada bentuk teks, grafik, audio, video, dan lain-lain. 
Multimedia merupakan penyatuan dua atau lebih media komunikasi misalnya teks, grafik, animasi, audio dan video yang menggunakan karakteristik-karakteristik interaktivitas personal komputer untuk membuat satu presentasi menarik. Merujuk Lirahman dan Heniwaty (2019), ada empat model multimedia interaktif yaitu model drills, model tutorial, model simulasi, dan model games. Dari keempat model tersebut dipilih model simulasi sebagai multimedia interaktif dalam penelitian. Model simulasi bisa menyajikan materi konfigurasi elektron secara menarik karena dapat menjelaskan pada siswa mengenai perputaran elektron pada kulit atom yang mengelilingi inti atom.

Berdasarkan Rafmana et al. (2018), dan Hadza et al. (2020), multimedia interaktif berbasis Articulate Storyline dapat menjadi pembangkit motivasi peserta didik dan rangsangan terhadap kegiatan belajar peserta didik jika produksinya direncanakan secara tepat. Produk media pembelajaran interaktif Konfigurasi Elektron yang berbasis Articulate Storyline telah diproduksi dengan tepat.

Berdasarkan grafik 1, terlihat bahwa evaluasi yang diberikan sang ahli isi terhadap beberapa komponen/aspek uji ahli isi adalah sebagai berikut: (1) evaluasi kelayakan aspek materi rata-rata sebanyak 96,67\%, termasuk pada kriteria sangat baik dan kategori sangat layak, (2) evaluasi kelayakan aspek kebahasaan rata-rata sebanyak $100 \%$, termasuk pada kriteria sangat baik dan kategori sangat layak, (3) evaluasi kelayakan aspek penyajian rata-rata sebanyak 100\%, termasuk pada kriteria sangat baik dan kategori sangat layak, (4) evaluasi kelayakan pengaruh media terhadap taktik pembelajaran rata-rata sebanyak $100 \%$, termasuk pada kriteria sangat baik dan kategori sangat layak, dan (5) evaluasi aspek tampilan menyeluruh rata-rata sebanyak 100\%, termasuk pada kriteria sangat baik dan kategori sangat layak. Sedangkan total evaluasi terhadap holistik komponen/aspek uji ahli isi rata-rata sebanyak 98,95\%, termasuk pada kriteria sangat baik dan kategori sangat layak.

Berdasarkan grafik 2, terlihat bahwa evaluasi yang diberikan sang ahli media terhadap beberapa komponen/aspek uji ahli media adalah sebagai berikut: (1) evaluasi kelayakan aspek media rata-rata sebanyak 93,33\%, termasuk pada kriteria sangat baik dan kategori sangat layak, (2) evaluasi kelayakan aspek materi rata-rata sebanyak $90 \%$, termasuk pada kriteria sangat baik dan kategori sangat layak, (3) evaluasi kelayakan aspek kebahasaan rata-rata sebanyak 88\%, termasuk pada kriteria sangat baik dan kategori sangat layak, (4) evaluasi kelayakan aspek penyajian rata-rata sebanyak $86,67 \%$, termasuk pada kriteria sangat baik dan kategori sangat layak, (5) evaluasi aspek dampak media terhadap taktik pembelajaran rata-rata sebanyak $90 \%$, termasuk pada kriteria sangat baik dan kategori sangat layak, dan (6) evaluasi kelayakan tampilan menyeluruh rata-rata sebanyak $85,71 \%$, termasuk pada kriteria sangat baik dan kategori sangat layak. Sedangkan total evaluasi terhadap holistik komponen/aspek uji ahli media rata-rata sebanyak $89,73 \%$, termasuk pada kriteria sangat baik dan kategori sangat layak.

Berdasarkan grafik 3, terlihat bahwa evaluasi yang diberikan sang ahli desain terhadap beberapa komponen/aspek uji ahli desain adalah sebagai berikut: (1) evaluasi kelayakan aspek media rata-rata sebanyak 95\%, termasuk pada kriteria sangat baik dan kategori sangat layak, (2) evaluasi kelayakan aspek kebahasaan rata-rata sebanyak 92\%, termasuk pada kriteria sangat baik dan kategori sangat layak, (3) evaluasi kelayakan aspek penyajian rata-rata sebanyak 100\%, termasuk pada kriteria sangat baik dan kategori sangat layak, (4) evaluasi aspek pengaruh media terhadap taktik pembelajaran ratarata sebanyak $90 \%$, termasuk pada kriteria sangat baik dan kategori sangat layak, dan (5) evaluasi kelayakan tampilan menyeluruh rata-rata sebanyak $85,71 \%$, termasuk pada kriteria sangat baik dan kategori sangat layak. Sedangkan total evaluasi terhadap holistik komponen/aspek uji ahli desain ratarata sebanyak $92,26 \%$, termasuk pada kriteria sangat baik dan kategori sangat layak.

Media pembelajaran interaktif Konfigurasi Elektron Elektronik Otomatis yang berbasis Articulate Storyline dalam mata pelajaran IPA menggunakan materi konfigurasi elektron bisa menaikkan motivasi belajar peserta didik, hal tadi dibuktikan menggunakan ketuntasan belajar klasikal sebanyak 88,13\%. Penelitian pengembangan yang relevan Rafmana et al. (2018), juga memberitahukan output penelitian yang sama, produk multimedia interaktif berbasis Articulate Storyline yang dikembangkan 
dinyatakan memiliki dampak potensial untuk menaikkan motivasi belajar peserta didik pada Sekolah Menengah Atas Srijaya Negara Palembang sebesar 82.1\%, kategori motivasi belajar tinggi. Demikian juga penelitian lain Astiningsih dan Partana (2020), dengan judul Using Android Media for Chemistry Learning Construction of Motivation and Metacognition Ability, menunjukkan bahwa skor motivasi variable sebesar 0,038 dan skor sig. 0,124 artinya lebih besar dari $\alpha=0,05$, sehingga $\mathrm{H}_{0}$ diterima.

Pembelajaran Jarak Jauh di Indonesia selama Pandemi COVID-19 dipengaruhi oleh kesiapan teknologi berdasarkan kurikulum humanis nasional, dukungan dan kerja sama seluruh pemangku kepentingan, termasuk pemerintah, sekolah, pendidik, orang tua dan komunitas (Rasmitadila et al., 2020). Kehadiran media pembelajaran interaktif Konfigurasi Elektron Elektronik Otomatis memiliki arti dan makna yang relatif krusial pada proses belajar mengajar. Berdasarkan output angket dalam uji coba lapangan sebanyak $99,06 \%$ peserta didik menyatakan bahwa ketidakjelasan bahan bahan ajar yang disampaikan bisa dibantu menggunakan media.

Produk media pembelajaran interaktif Konfigurasi Elektron Elektronik Otomatis yang berbasis Articulate Storyline, diterapkan dalam mata pelajaran IPA menggunakan materi konfigurasi elektron kelas IX Sekolah Menengah Pertama Negeri 1 Wonoayu Sidoarjo pada masa pandemi COVID-19. Berdasarkan output penelitian sebelumnya bisa disimpulkan bahwa multimedia interaktif berbasis Articulate Storyline bisa sebagai pembangkit motivasi bagi peserta didik. Selain itu multimedia interaktif bisa mengatasi banyak sekali kendala pada Pembelajaran Jarak Jauh di Indonesia selama pandemi COVID-19, hal tadi merujuk Pakpahan dan Fitriani (2020), yang menyatakan bahwa Pembelajaran Jarak Jauh (PJJ) di masa pandemi COVID-19 adalah pembelajaran dengan pemanfaatan Teknologi Informasi yang menggunakan perangkat komputer atau gadget yang saling terhubung antara peserta didik dan pendidik.

\section{SIMPULAN}

Media pembelajaran interaktif Konfigurasi Elektron Elektronik Otomatis yang berbasis Articulate Storyline bisa memudahkan penyampaian materi pada proses pembelajaran secara DARING dan LURING. Dengan demikian media pembelajaran interaktif Konfigurasi Elektron Elektronik Otomatis bisa meningkatkan minat dan motivasi belajar dalam Pembelajaran Jarak Jauh (PJJ) selama masa pandemi COVID-19. Peserta didik sangat bahagia mengikuti pembelajaran IPA dan menyatakan tidak bosan. Media pembelajaran interaktif Konfigurasi Elektron Elektronik Otomatis efektif menaikkan output belajar peserta didik dalam mata pelajaran IPA menggunakan materi konfigurasi elektron kelas IX Sekolah Menengah Pertama Negeri 1 Wonoayu Sidoarjo. Dari produk yang dikembangkan dan menurut output review sang ahli isi, ahli media dan ahli desain, kesimpulannya produk media pembelajaran interaktif Konfigurasi Elektron Elektronik Otomatis sudah dinyatakan sangat layak diimplementasikan dengan beberapa tips perbaikan yang menyertainya.

\section{DAFTAR RUJUKAN}

Abidin, Z., Rumansyah, dan Arizona, K. (2020). Pembelajaran Online Berbasis Proyek Salah Satu Solusi Kegiatan Belajar Mengajar Di Tengah Pandemi Covid-19. Jurnal Ilmiah Profesi Pendidikan. https://doi.org/10.29303/JIPP.V5I1.111

Amirudin, N. (2019). Problematika Pembelajaran Pendidikan Agama Islam di Era Digital. Prosiding Seminar Nasional PAI Dengan Pendekatan Multidisipliner.

Andriani, W., Setyosari, P., Kuswandi, D., Kamdi, W., Gunawan, W., dan Karyono, H. (2020). Application of MURDER Collaborative Learning and Achievement Motivation on ProblemSolving Skills. International Journal of Innovation, Creativity and Change. Www.Ijicc.Net, 14(2), 2020. www.ijicc.net

Arifin, R. W., Septanto, H., dan Wignyowiyoto, I. (2018). Pengembangan Media Pembelajaran Berbasis Video Animasi Dengan Model ADDIE Dalam Kegiatan Pembelajaran Blended Learning. Vol 2 No 2 (2018): Information Management For Educators and Professionals (Juni 2018). 
Astiningsih, A. D., dan Partana, C. F. (2020). Using Android Media for Chemistry Learning Construction of Motivation and Metacognition Ability. International Journal of Instruction. https://doi.org/10.29333/iji.2020.13119a

Aulia, J., P, N. D. P., Zarkasih, dan Nova, T. L. (2020). Meta-Analisis Pengaruh Penerapan Pendekatan Saintifik Berbantuan Komik Terhadap Hasil Belajar IPA Peserta didik SMP. JNSI: Journal of Natural Science and Integration, 3(1), 70-76.

Cahyadi, R. A. H. (2019). Pengembangan Bahan Ajar Berbasis ADDIE Model. Halaqa: Islamic Education Journal, 3(1), 35. https://doi.org/10.21070/halaqa.v3i1.2124

Darnawati, Batia, L., Irawaty, dan Salim. (2019). Pemberdayaan Guru Melalui Pengembangan Multimedia Pembelajaran Interaktif dengan Aplikasi Articulate Storyline. Jurnal Pengabdian Kepada Masyarakat.

Fatirul, A. N. (2020). Online Application Development in Blended Learning to Increase Ease of Collaboration and Communication and Students Freedom of Thought Ability. International Journal of Arts and Social Science ISSN: 2581-7922, 3(5), 112-118. www.ijassjournal.com

Fatirul, A. N., dan Rufi'i. (2020). Evaluasi dan Pengukuran (I. Wiryokusumo (ed.)). Adi Buana University Press.

Hadza, C., Sesrita, A., dan Suherman, I. (2020). Development of Learning Media Based on Articulate Storyline. Indonesian Journal of Applied Research (IJAR). https://doi.org/10.30997/ijar.v1i2.54

Hakim, L. (2018). Pengembangan Media Pembelajaran PAI Berbasis Augmented Reality. Lentera Pendidikan: Jurnal Ilmu Tarbiyah Dan Keguruan, 20(1), 59-72.

Hamdani, A. R., dan Priatna, A. (2020). Efektifitas Implementasi Pembelajaran DARING (Full Online) di Masa Pandemi COVID-19 pada Jenjang Sekolah Dasar di Kabupaten Subang. Didaktik : Jurnal Ilmiah PGSD STKIP Subang. https://doi.org/10.36989/didaktik.v6i1.120

Herdiyanto, D., Sulton, S., dan Praherdhiono, H. (2020). Pengembangan Multimedia Pembelajaran Interaktif pada Materi Tema Tanah bagi Peserta didik Tunagrahita. JKTP: Jurnal Kajian Teknologi Pendidikan. https://doi.org/10.17977/um038v3i12019p088

Iswara, G. P. S., Kuswandi, D., dan Husna, A. (2020). Pengembangan Multimedia Interaktif Dilengkapi dengan Simulasi untuk Memvisualisasikan Reaksi Kimia Pada Materi Larutan Penyangga SMA Kelas XI. JINOTEP (Jurnal Inovasi Teknologi Pembelajaran), 6(2), 58-68. https://doi.org/10.17977/um031v6i22020p058

Lirahman, R., dan Heniwaty, Y. H. (2019). Pengembangan Pembelajaran Tari Lenggok Mak Inang melalui Multimedia Interaktif Berbasis E-Learning. Gesture: Jurnal Seni Tari. https://doi.org/10.24114/senitari.v8i1.13193

Luhulima, D. A. (2018). Pengembangan Media Video Animasi untuk Materi Pembelajaran Karakter Bersaksi di Sekolah Minggu. Jurnal Pendidikan Agama Kristen, 4(16).

Mahmudah, A., dan Pustikaningsih, A. (2019). Pengembangan Media Pembelajaran Interaktif Berbasis Lectora Inspire Pada Materi Jurnal Penyesuaian Untuk Peserta didik Kelas X Akuntansi dan Keuangan Lembaga SMK Negeri 1 Tempel Tahun Ajaran 2018/2019. Jurnal Pendidikan Akuntansi Indonesia. https://doi.org/10.21831/jpai.v17i1.26515

Molenda, M. (2015). In Search of the Elusive ADDIE Model. Performance Improvement. https://doi.org/10.1002/pfi.21461

Munir. (2020). Multimedia Konsep dan Aplikasi dalam Pendidikan. In Antimicrobial agents and chemotherapy.

Novianto, L. A., Degeng, I. N. S., dan Wedi, A. (2018). Pengembangan Multimedia Interaktif Mata Pelajaran IPA Pokok Bahasan Sistem Peredaran Darah Manusia Untuk Kelas VIII SMP Wahid Hasyim Malang. Jurnal Kurikulum Teknologi Pendidikan (JKTP) Universitas Negeri Malang.

Noviyanti, N., dan Gamaputra, G. (2020). Model Pengembangan ADDIE Dalam Penyusunan Buku Ajar Administrasi Keuangan Negara (Studi Kualitatif di Prodi D-III Administrasi Negara FISH 
Unesa). Jurnal Ilmiah Manajemen Publik Dan Kebijakan Sosial. https://doi.org/10.25139/jmnegara.v4i2.2458

Nugroho, M., F., A., Wahida, A., dan Margana. (2020). Pengembangan Media Pembelajaran Video Tutorial Melukis Teknik Aquarel di SMA Negeri 3 Surakarta Tahun Ajaran 2020. Prosiding Seminar Nasional Desain Dan Arsitektur (SENADA), 3, 318-323. http://senada.std-bali.ac.id

Pakpahan, R., dan Fitriani, Y. (2020). Analisa Pemanfaatan Teknologi Informasi dalam Pembelajaran Jarak Jauh di Tengah Pandemi Virus Corona COVID-19. JISAMAR (Journal of Information System, Applied, Management, Accounting and Researh), 4(2), 30-36.

Prawiyogi, A. G., Purwanugraha, A., Fakhry, G., dan Firmansyah, M. (2020). Efektifitas Pembelajaran Jarak Jauh terhadap Pembelajaran Peserta didik di SDIT Cendekia Purwakarta. Jurnal Pendidikan Dasar.

Pujianto, H., H., Marianus, S., dan Rusmawati, R., D. (2020). Aplikasi Berbasis Android untuk Meningkatkan Kemampuan Berbahasa pada Anak Tuna Rungu Peserta didik TKLB. Jurnal Education and Development Institut Pendidikan Tapanuli Selatan, 8(2), 390-398. http://journal.ipts.ac.id/index.php/ED/article/view/1728/866

Rafmana, H., Chotimah, U., dan Alfiandra. (2018). Pengembangan Multimedia Interaktif Berbasis Articulate Storyline untuk Meningkatkan Motivasi Belajar Peserta didik pada Mata Pelajaran PKN Kelas XI di SMA Sriwijaya Negara Palembang. Jurnal Bhinneka Tunggal Ika.

Rasmitadila, Aliyyah, R. R., Rachmadtullah, R., Samsudin, A., Syaodih, E., Nurtanto, M., dan Tambunan, A. R. S. (2020). The Perceptions of Primary School Teachers of Online Learning during the COVID-19 Pandemic Period: A Case Study in Indonesia. Journal of Ethnic and Cultural Studies, 7(2), 90-109. http://dx.doi.org/10.29333/ejecs/388

Saputri, M. E. E., dan Oktarin, I. B. (2019). Pengembangan Modul Pembelajaran Berbasis Penemuan Terbimbing Pada Mata Kuliah Matematika Ekonomi. Jurnal Teknologi Pendidikan (JTP), 12(2), 155. https://doi.org/10.24114/jtp.v12i2.15230

Satianingsih, R., Budiyono, S. C., dan Subandowo, M. (2020). Character Education in Multicultural Society: Case in Indonesia. International Journal of Multicultural and Multireligious Understanding, 7(4), 337-344. http://dx.doi.org/10.18415/ijmmu.v7i4.1407

Setyaningsih, S., Rusijono, R., dan Wahyudi, A. (2020). Pengaruh Penggunaan Media Pembelajaran Interaktif Berbasis Articulate Storyline terhadap Motivasi Belajar dan Hasil Belajar Peserta didik pada Materi Kerajaan Hindu Budha di Indonesia. Didaktis: Jurnal Pendidikan Dan Ilmu Pengetahuan. https://doi.org/10.30651/didaktis.v20i2.4772

Sudibjo, A. (2019). Penggunaan Media Pembelajaran IPA Berbasis Google Classroom pada Materi Alat Optik untuk Meningkatkan Respons Motivasi dan Hasil Belajar Peserta didik di SMP Negeri 4 Surabaya. Jurnal Education and Development, 7(3), 278-284.

Supratman, E., dan Purwaningtias, F. (2018). Pengembangan Media Pembelajaran E-Learning Berbasis Schoology. Jurnal Informatika: Jurnal Pengembangan IT. https://doi.org/10.30591/jpit.v3i3.958

Wahyuningtyas, R. (2019). Pentingnya Media dalam Pembelajaran guna Meningkatkan Hasil Belajar di Sekolah Dasar. Jurnal Ilmu Pendidikan, 1(1), 222-232. https://edukatif.org/index.php/edukatif/index

Wijayanti, H. (2020). Pengembangan Bahan Ajar Berbasis E-Learning pada Pembelajaran Tematik Kelas 3 Tema 6: Energi dan Perubahannya. Universitas PGRI Adi Buana Surabaya.

Yahya, R., Ummah, S. K., dan Effendi, M. M. (2020). Media Pembelajaran Interaktif Articulate Storyline: Pengembangan Perangkat Pembelajaran Flipped classroom Bercirikan Mini-project. SJME (Supremum Journal of Mathematics Education). https://doi.org/10.35706/sjme.v4i1.3136

Yuda, A. B. S., Degeng, I. N. S., dan Soepriyanto, Y. (2020). Pengembangan Puzzle Game Tentang Keragaman Budaya Indonesia Berbantuan Interactive Whiteboard. JKTP (Jurnal Kajian Teknologi Pendidikan), 3(4), 425-434. https://doi.org/10.17977/um038v3i42020p425 